\title{
Developing Learning Media Assisted-flash Macromedia Software by Applying Discovery Model to Improve Students' Concept and Self Regulated Learning on Senior High School
}

\author{
Nurliyah Nasution ${ }^{1}$, Bornok Sinaga $^{2}$, Mukhtar $^{3, *}$ \\ ${ }^{1}$ Education of Mathematics Post Graduation, Universitas Negeri Medan \\ ${ }^{2}$ Department of Mathematics Education, Universitas Negeri Medan \\ ${ }^{3}$ Department of Mathematics Education, Universitas Negeri Medan, Medan, Indonesia \\ *Corresponding author: nurliyahnasution@gmail.com
}

Received December 20, 2018; Revised January 25, 2019; Accepted February 18, 2019

\begin{abstract}
Problem root of this research is the low students Mathematic learning outcome and Mathematic learning orientation happened recently did not emphasize students to have appropriate conceptual understanding. This causes the decrease of students' conceptual understanding, so they are not able to complete Mathematic problems given and tend not to study independently. To overcome this problem in this research Macromedia Flash learning media Is developed which is implemented by using discovery learning model which aims at increasing students conceptual understanding and grow students' independent learning. Process of developing learning media in this study is conducted to find out validity, practicality and effectiveness of that media. Data of the study shows that learning media developed has met the level of validity, practicality and effectiveness. The results of validity are at a valid level; practicality seen from the implementation of learning media is at high level and the effectiveness seen from students' response shows positive result, time management of students is ideal, and students' learning outcomes are good. The student learning independence questionnaire after the learning process using media is increasing.
\end{abstract}

Keywords: learning media, discovery learning, the ability to understand concepts and self regulated learning

Cite This Article: Nurliyah Nasution, Bornok Sinaga, and Mukhtar, "Developing Learning Media Assisted-flash Macromedia Software by Applying Discovery Model to Improve Students' Concept and Self Regulated Learning on Senior High School.” American Journal of Educational Research, vol. 7, no. 2 (2019): 161-165. doi: 10.12691/education-7-2-7.

\section{Introduction}

Modern education goal is to train students to have long live learning and right in taking decisions. Learning as a process to gain knowledge, skills, and routines will be more effective if new knowledge gained from some learning experiences is facilitated by multimedia [1]. Related to this issue, Depdiknas [2] states that Mathematic is universal knowledge which underlies the development of modern technology; it has an important role in various disciplines and develops human thinking ability. Moreover, National Council of Teachers of Mathematic [3] formulates some Mathematic instructional goals, they are learning to communicate (mathematical communication), learning to reason (mathematical reasoning), learning to solve problems (mathematical problem solving), learning to associate ideas (mathematical connection), and learning to represent ideas (mathematical representation). In reality, students' Mathematic ability at MAN Simalungun was low. It is in line with a study conducted by Hasibuan [4] the study showed that there were many students who individually did not understand Mathematic concepts which are basically deductive axiomatic started from abstract things. Regarding teaching learning process emphasized in reasoning, developing critical attitude, logic and the application of mathematical skills, students have to have the ability to understand mathematical concepts as the main prerequisite. Besides a good conceptual understanding of Mathematic, self regulated learning is another essential component in learning Mathematic which needs to enhance. The autonomous learning determines whether or not the students are successful in learning, and it provides positive effect in students' learning and learning outcome. This statement is supported by researches conducted by Darr and Fisher, Pintrich and Groot [5] which propose that self regulated learning correlates strongly with students success in learning.

To solve the problem in this study, learning media is developed by using Flash Macromedia Software which aims at enhancing students' conceptual understanding and self regulated learning. According Ahmad [6] using media 
in form of technology in learning Mathematic is requisite to develop students' learning motivation, higher order thinking skill, and student-to student communication skill. In other research Gebreyohannes [7], asserts that the use of multimedia in teaching learning process affects higher institutional education. Sensory multimedia is able to stimulate many senses of the audience at once; its interactive nature allows the teacher to control the flow of informationother research. A research organized by Sinarut [8] appoints that learning media assisted with flash programs that are valid, practical and effective can improve students' mathematical communication skills.

The use of media in the learning process requires collaboration with learning models that support teaching and learning activities because when the process is assisted by the learning model that is in progress, it can be more efficient and well conceptualized. If learning by using interesting concepts is not planned well with, learning will be boring and not efficient. To choose an appropriate model, the researcher must be able to adjust to the model to students' learning achievement. The learning model used in this study is discovery learning. Mulyatiningsih [9] suggests that the steps of discovery learning that teachers have including: Explaining the purpose of learning, and dividing the experimental instructions. Students carry out experiments under the supervision of the teacher, the teacher shows the indications observed, and finally students conclude the experimental results. Furthermore Yusnawan [10] contends that discovery learning provides opportunities for students to compile, process, and organize data provided by the teacher. Through the process of this discovery, students are required to use their own ideas and understanding to find something new, so that understanding of students' Mathematic concepts is increase. According Balm [11] in finding concepts, students conduct observations, classifications, make guesses, explain, and draw conclusions to find some concepts or principles. The research conducted by Damanik [12] shows that the development of learning devices by using discovery learning models can improve students' creative thinking abilities in which in the first try out the percentage of completeness was $70 \%$ and it increased to $8 \%$ in the second try out.

\section{Research Methods}

This is a research and development / R \& D study; it produces certain products and tests the effectiveness of these products [13]. The development of learning media in this study uses the development model proposed by Dick \& Carey (Borg \& Gall) [14] they reveal that educational development research is a work based on a development model to find out a research to design new products and procedures systematically by having field testing, evaluation, and data filtering to gain specific criteria of effectiveness, quality, and standardization. In this study development products will be produced; it is a learning media of Mathematic by applying discovery learning models in Matrix Chapter. Procedural steps for developing the Dick \& Carey model [15] in this study include: 1) identifying objectives, 2) conducting teaching analysis, 3) conducting student analysis and context, 4) formulating performance goals, 5) developing assessment instruments, 6) developing teaching strategies, 7) developing teaching materials and media, 8) designing and carrying out formative tests, 9) revising, 10) designing and carrying out summative tests. Those ten steps for developing learning devices and their assessment are shown in the following scheme.

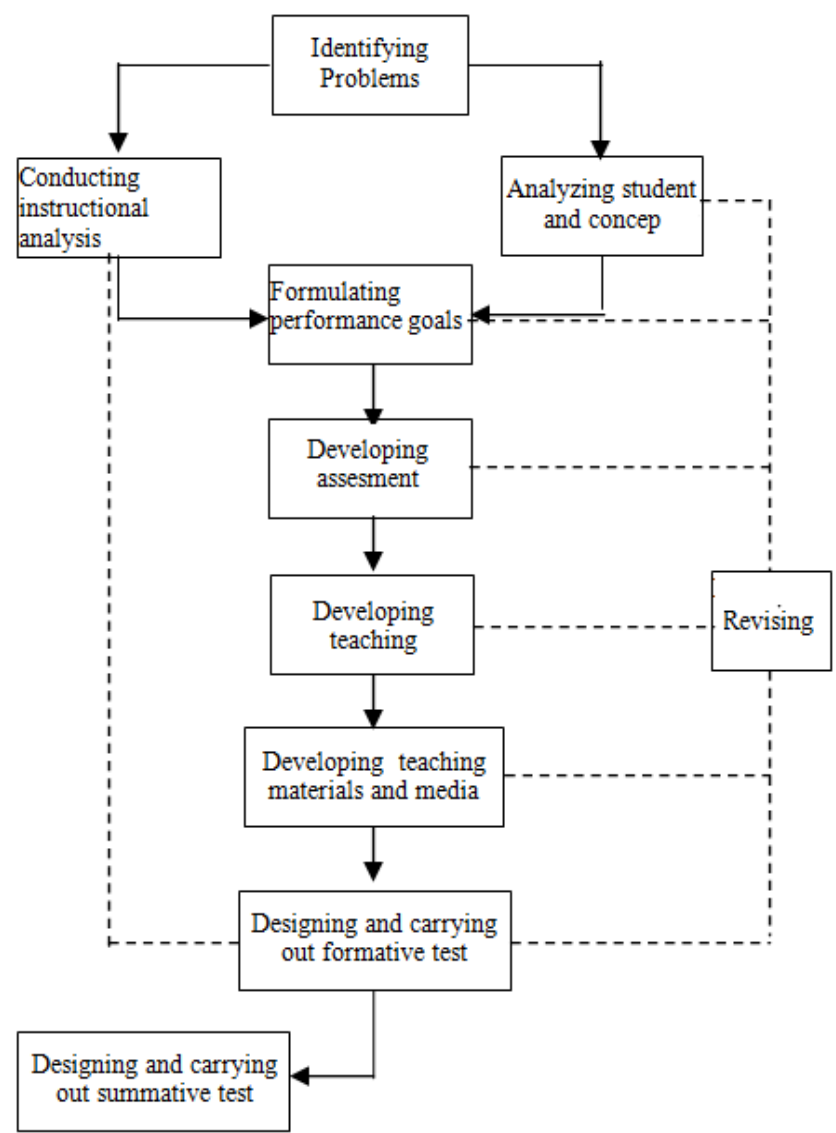

Figure 1. Model of Learning Media Development

The subjects of this study are students of XIIPA1 and XIIPA3, MAN Simalungun; each class 40 students. The first try out is conducted in the XIIPA1 and the second try out is conducted in the XIIPA3, while the object of this research is learning media using the macromedia flash software by implementing discovery learning model.

The instruments used in this study are tests of conceptual comprehension, autonomous learning questionnaires, learning observation sheets and student response questionnaires. Furthermore, the data obtained is analyzed to determine the validity, practicality and effectiveness of learning media with discovery learning models. A) The validity of learning media is obtained based on data analysis results of the learning media assessment sheet of expert lecturers and Mathematic teachers. B) Practicality of learning media is acquired from teaching learning process observation sheet used as a guideline in observing instructional media developed in the implementation of teaching learning process in classroom. According Sinaga [16] the implementation of learning media is measured from three aspects of observation / assessment, namely 1) the implementation of learning syntax, 2) the implementation of social systems and 3) the principle of management records. Observations are made during the learning process. C) According Nieven [17] data on the 
effectiveness of learning media are measured from three aspects of assessment, namely 1) achievement of student learning outcomes 2) achievement of student activity in the teaching learning process 3 ) and student responses to learning using media. The technique used to obtain data validity is by providing learning media and assessment sheets to experts and practitioners.

Furthermore, experts and practitioners give rate for each indicator in each aspect of the assessment consisting of 5 (five) rating scales. To obtaining data effectiveness and practicality, the researcher gives teaching learning process observation sheet and observation sheet of student activities during the learning process to observers. Then, they rate each observation indicators. In each aspect of the assessment, there are 5 (five) rating scales. Likewise, the student response questionnaire and autonomous learning questionnaire consist of 5 (five) rating scales.

\section{Research Findings and Discussion}

This research is a development research to develop a learning media, so the product of this research is learning media applying discovery learning models. The objectives of this development are: (1) to describe the validity, practicality and effectiveness of learning media based on discovery learning models; (2) to describe an increase in the ability to understand concepts through the use of learning media based on discovery learning models and (3) to depict an increase in student learning independence.

\subsection{Results of Learning Media Validation Based on Discovery Learning Model}

The results of the learning media validation for each instrument can be seen in the following table:

Table 1. Average Value of Indicators for Each Aspect in Assessing the Validity of Learning Media

\begin{tabular}{|c|c|c|c|c|c|c|c|}
\hline \multirow[t]{2}{*}{ Aspect } & \multicolumn{5}{|c|}{ Validatee } & \multirow[t]{2}{*}{ Average } & \multirow[t]{2}{*}{$\begin{array}{l}\text { Total of } \\
\text { Average }\end{array}$} \\
\hline & 1 & 2 & 3 & 4 & 5 & & \\
\hline $\begin{array}{l}\text { Quality of } \\
\text { Media Design }\end{array}$ & 4,7 & 4,7 & 4,2 & 4,5 & 4,7 & 4,6 & \multirow{5}{*}{4,35} \\
\hline Presentation & 4,2 & 4,2 & 4,2 & 4,2 & 4,5 & 4,3 & \\
\hline $\begin{array}{l}\text { Quality of } \\
\text { Interactive }\end{array}$ & 4 & 4,5 & 4 & 4 & 4 & 4,1 & \\
\hline $\begin{array}{l}\text { Quality of } \\
\text { Percentage }\end{array}$ & 4,7 & 4,2 & 4 & 5 & 4,7 & 4,5 & \\
\hline $\begin{array}{l}\text { Quality of } \\
\text { Content }\end{array}$ & 4,7 & 4 & 3,7 & 4,2 & 4,5 & 4,2 & \\
\hline
\end{tabular}

The table above shows that each arning media validity instrument developed is considered valid with average score is 4.35 .

\subsection{Result of Implementation of Learning Media}

The observation results of the learning media implementation for 4 meetings can be seen in the following table.
Table 2. Average of Indicator Value for Each Aspect of Learning Media Implementation in $1^{\text {st }}$ try out

\begin{tabular}{|c|l|c|c|c|c|c|}
\hline \multirow{2}{*}{ No } & \multirow{2}{*}{ aspects Observed } & \multicolumn{4}{|c|}{$\begin{array}{c}\text { Average score for each } \\
\text { observation aspect of } \\
\text { in } 1^{\text {st }} \text { try out }\end{array}$} & \multirow{2}{*}{$\begin{array}{c}\text { Value of } \\
\text { Aspect }\end{array}$} \\
\cline { 3 - 6 } & & 1 & 2 & 3 & 4 & \\
\cline { 3 - 6 } & & 2,8 & 3 & 2,8 & 2,9 & 2,9 \\
\hline I & Syntax & 2,8 & 3 & 3,2 & 3 & 3 \\
\hline II & Social System & 2,8 & 3,1 & 2,9 & 3 & 3 \\
\hline III & $\begin{array}{l}\text { Management } \\
\text { Principles }\end{array}$ & \multicolumn{5}{|c|}{ Meeting } \\
\hline \multicolumn{7}{|c|}{ Total of average $1^{\text {st }}$ try out aspect } \\
\hline
\end{tabular}

Table 3. Average of Indicator Value for Each Aspect of Learning Media Implementation in $2^{\text {nd }}$ Try Out

\begin{tabular}{|c|l|c|c|c|c|c|}
\hline \multirow{2}{*}{ No } & \multirow{2}{*}{$\begin{array}{l}\text { Aspects } \\
\text { Observed }\end{array}$} & \multicolumn{3}{|c|}{$\begin{array}{c}\text { Average score for each } \\
\text { observation aspect of } \\
\text { in 2 }\end{array}$} & \multirow{2}{*}{$\begin{array}{c}\text { Value of } \\
\text { Aspect }\end{array}$} \\
\cline { 3 - 6 } & & \multicolumn{4}{|c|}{ Meeting } \\
\cline { 2 - 5 } & 1 & 2 & 3 & 4 & \\
\hline I & Syntax & 4.3 & 4.5 & 4 & 4. & 4.2 \\
\hline II & Social System & 4.4 & 4.2 & 4 & 4.2 & 4.2 \\
\hline III & $\begin{array}{l}\text { Management } \\
\text { Principles }\end{array}$ & 4.2 & 3.8 & 4 & 4 & 4 \\
\hline
\end{tabular}

The average indicator value in the table above is obtained from the results of the indicator values for each aspect of observation divided by the indicators of that aspect. Average rate for $1^{\text {st }}$ try out aspect is 2.96 . Revision for learning media is conducted and then it is tried at second try out which showed 4.13 average rate, at the high level.

\subsection{Result of Learning Media Effectiveness Analysis}

Table 4. Value of Conceptual Understanding Ability of Students of XI-IPA1 and XI-IPA3 $1^{\text {st }}$

\begin{tabular}{|l|l|c|c|}
\hline \multirow{2}{*}{$\begin{array}{l}\text { Interval } \\
\text { Value }\end{array}$} & \multirow{2}{*}{ Predicate } & $\begin{array}{c}\text { Frequency of } \\
\text { Pretest Rate }\end{array}$ & $\begin{array}{c}\text { Frequency of } \\
\text { Posttest Rate }\end{array}$ \\
\cline { 3 - 4 } & & \multicolumn{2}{|c|}{$1^{\text {st }}$ try out } \\
\hline $3,49-4,00$ & $\mathrm{~A}$ & 0 & 0 \\
\hline $3,04-3,48$ & $\mathrm{~B}$ & 0 & 8 \\
\hline $2,56-3$ & $\mathrm{C}$ & 4 & 20 \\
\hline$<2,56$ & $\mathrm{D}$ & 36 & 12 \\
\hline Total & $\mathbf{4 0}$ & $\mathbf{4 0}$ \\
\hline Average Score & $\mathbf{3 9}$ & $\mathbf{6 8 , 1 5}$ \\
\hline Standard Deviation Score & $\mathbf{1 3 , 3 3}$ & $\mathbf{9 , 0 2}$ \\
\hline Completeness Level (\%) & $\mathbf{0 \%}$ & $\mathbf{2 0 \%}$ \\
\hline
\end{tabular}

Table 5. Value of Conceptual Understanding Ability of Students of XI-IPA1 and XI-IPA3 $2^{\text {nd }}$

\begin{tabular}{|c|c|c|c|}
\hline \multirow{2}{*}{$\begin{array}{c}\text { Interval } \\
\text { Value }\end{array}$} & Predicate & $\begin{array}{c}\text { Frequency of } \\
\text { Pretest Rate }\end{array}$ & $\begin{array}{c}\text { Frequency of } \\
\text { Posttest Rate }\end{array}$ \\
\cline { 2 - 4 } & $\mathrm{A}$ & 0 & 8 \\
\hline $3,49-4,00$ & $\mathrm{~A}$ & 0 & 27 \\
\hline $3,04-3,48$ & $\mathrm{~B}$ & 3 \\
\hline $2,56-3$ & $\mathrm{C}$ & 0 & 2 \\
\hline$<2,56$ & $\mathrm{D}$ & 40 & $\mathbf{4 0}$ \\
\hline \multicolumn{2}{|c|}{ Total } & $\mathbf{4 0}$ & $\mathbf{7 9 , 1}$ \\
\hline \multicolumn{2}{|c|}{ Average Score } & $\mathbf{4 4 , 5}$ & $\mathbf{8 , 6 1}$ \\
\hline \multicolumn{2}{|c|}{ Standard Deviation Score } & $\mathbf{1 2 , 0 8}$ & $\mathbf{8 7 , 5 \%}$ \\
\hline \multicolumn{2}{|c|}{ Completeness Level (\%) } & $\mathbf{0 \%}$ & \\
\hline
\end{tabular}


Table above presents that in $1^{\text {st }}$ try out percentage of students' learning achievement is $20 \%$, after a revision is given to learning media it is improved to $87.5 \%$. This indicates that learning media developed in terms of learning outcomes have met the effective criteria. Additionally, the effectiveness of learning seen from achievement of students' autonomous learning independence in the second try out can be seen as follows:

Table 6 presents that percentage of students' autonomous learning is at high level in each indicators after learning by using learning media developed. The data represents that learning media developed seen from students' autonomous learning has met effective criteria.

Further, to find out the effectiveness of learning media developed seen from level of students' activities is established by having observation to see students' activities when they are listening to teacher's explanation, students' reading activities, and interaction with learning media to solve the problems given, writing activities, discussion activities, and activities irrelevant to instructional; process. Every aspect of student activity is observed by observers when the learning is being processed. Observation I is for listening activities, observation II is for activity of reading and interacting with the media in solving problems, observation III is the activity of writing observations, observation IV is the activity of discussing / questioning, observation $\mathrm{V}$ is activity which is not relevant when learning is taking place. The results of observations can be seen in the following diagram.

The biggest time proportion of students used during teaching and learning activities is writing activities (writing important things from the explanation of the teacher/friend, solving problems in the LAS, making a summary), which is $36.81 \%$ of the time available for each meeting.

This shows that during learning activities, students are more dominant in interacting with the media and solving problems in the media. The average percentage of time that students have for listening to teacher's/friend explanation is $20.90 \%$ of the time available for each meeting. Percentage of this activity is at ideal time set of tolerated interval. This indicates that the use of media in learning which uses discovery learning model by having scientific learning approach can limit teacher dominance in student activities. Percentage of student activities in discussing / asking friends and activities of students discussing / asking questions to teachers has 33.18\%. This indicates that the use of media in learning by applying the discovery model can condition students to discuss, help each other in solving problems. If there are problems experienced by students, they first discuss / ask their friends, do not immediately ask the teacher. The percentage of this activity is still within the tolerance limit of achieving the percentage of ideal time set. The average percentage of time students having activities that are not relevant to learning is $2.72 \%$ of the meeting time. This indicates that during the learning activities in each meeting there were always students who did activities irrelevant to learning (not doing their assignments/playing games, teasing their friends, going out of class). But the percentage of this activity is still at the specified ideal time tolerance interval.

Overall, if the average percentage of student activity (listening / paying attention to the teacher / friend's explanation) is 20.90\%; reading students books and LAS is $36.81 \%$; taking note of the teacher's explanation, taking note from books or from a friend, answering problems/questions in the LAS, summarizing the group's work is $30.90 \%$; Discussing / asking questions between students and teachers, students and students is $33.18 \%$; and doing irrelevant Activities to learning is $2.72 \%$ ), referred to the criteria for achieving the percentage of ideal student activity time set, it can be concluded that the percentage of student activity time in learning has met the criteria for achieving the percentage of ideal time set. The data shows that learning media developed in terms of student learning activities have met the effective criteria.

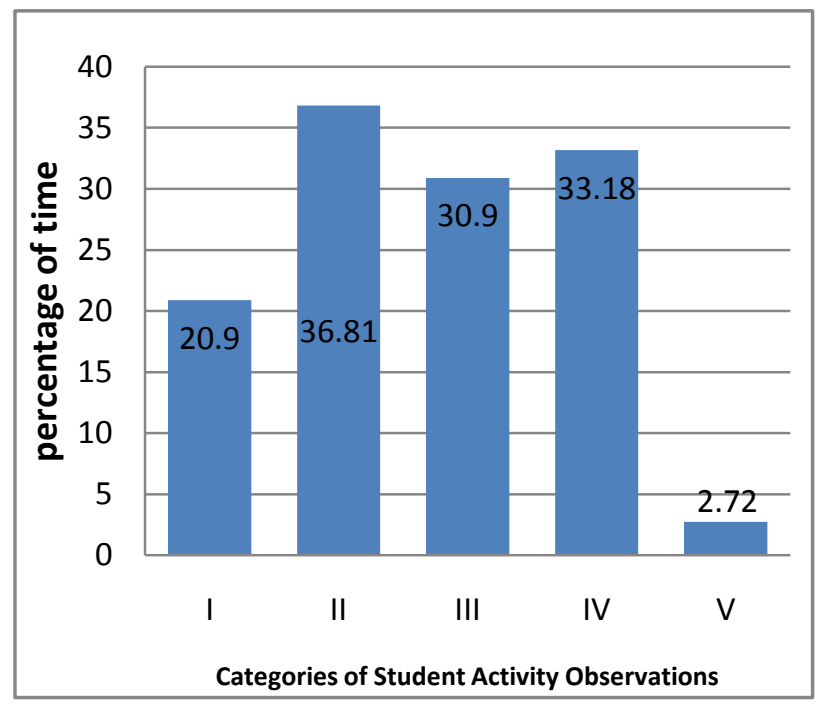

Figure 2. Presentation of student activity average

Table 6. Percentage of Scores Student Learning Independence in Trial $2^{\text {nd }}$

\begin{tabular}{|c|c|c|c|c|c|}
\hline No & Indicators & $\begin{array}{c}\text { Average Rate of Each } \\
\text { Indicator (\%) } \\
\text { Pretest }\end{array}$ & Category & $\begin{array}{l}\text { Average Rate of Each } \\
\text { Indicator (\%) } \\
\text { Posttest }\end{array}$ & Category \\
\hline 1 & Thinking Awareness in learning Mathematic & 70,35 & High & 90,75 & Very High \\
\hline 2 & Students Responses toward discovery learning model & 63,25 & High & 82,05 & Very High \\
\hline 3 & Students' motivation in learning Mathematic & 50,00 & Low & 88,05 & Very High \\
\hline 4 & Students' esteem in learning Mathematic & 61,05 & High & 87,50 & Very High \\
\hline
\end{tabular}


The results of the analysis of student response data can be seen as follows: 1) $90.41 \%$ of students enjoyed components and learning activities; 2) $84.58 \%$ of students revealed that the components and learning activities were still new; 3) $92.5 \%$ of students showed their interest to participate in Mathematic learning for different chapter by using learning media and applying discovery learning model; and 4) $91.25 \%$ of students expressed interest in the presentation of macromedia flash learning media combined with student books, LAS, image illustrations and image locations were clear in terms of readability, language use, and punctuation. If the results of this analysis are referred to the established criteria, it can be concluded that students' responses to the components and learning activities by using the macromedia flash learning media which apply the discovery model are positive. The data shows that the learning media developed seen from student responses have met the effective criteria

\section{Conclusion}

Generally, learning media developed is completely fulfilled validity level, the results of practicality of learning media in terms of expert opinion and on the implementation of learning media in the learning process are also in the high category. Likewise, the learning media effectiveness developed in terms of learning outcomes (the ability to understand concepts) at the pretest and posttest increased in $1^{\text {st }}$ try out and 2 nd try out. The level of student autonomous learning was also increasing. The activities of students in the learning process have met the criteria for achieving the percentage of ideal time set. Furthermore, the effectiveness of learning media in terms of student responses toward the components and learning activities by using the learning media of macromedia flash applying the discovery model is positive. Based on the data obtained it can be concluded that the learning media assisted by Macromedia Flash software using discovery learning model can improve the understanding of concepts and student autonomous learning.

\section{References}

[1] Divzak. B. (2011), The Impact of Game-Based Learning on the Achievement of Learning Goals and Motivation for Learning Mathematics - Literature Review. JIOS, Vol. 35, No.1.
[2] Depdiknas. 2006. Permendiknas No.22 tahun 2006 Tentang Standar Isi untuk Satuan Pendidikan Dasar dan Menengah. Jakarta: Depdiknas.

[3] NCTM. 2000. Principle and Standards for School Mathematics. Reston: Viginia.

[4] Hasibuan, O: Surya, E : Syahputra, E. (2017), The Aplication of CTL to Improve Students Understanding Concept Ability by Matflash Graphic Media Assistance. IJARIIE-ISSN(O)-2395-4396.

[5] Arifin. F.; Herman. T. (2018). Pengaruh Pembelajaran E-Learning Model Web Centric Course Terhadap Pemahaman Konsep Dan Kemandirian Belajar Matematika Siswa. Jurnal Pendidikan Matematika. Volume 12, No. 2, Juli 2018, pp. 1-12.

[6] Ahmad, A; Sin Yin. T; Yue Fang. T; Hui Yen.Y; Wee How. K. (2010). Incorporating Multimedia as a Tool into Mathematics Education: A Case Study on Diploma Students in Multimedia University. Procedia Social and Behavioral Sciences 8 (2010) 594-599.

[7] Gebreyohanes, H.M; Hasan. R (2016). Impact of multimedia in teaching mathematics. International Journal of Mathematics Trends and Technology (IJMTT) - Volume 39 Number 1.

[8] Sinurat. M; Syahputra. E; Rajagukguk. W. (2015). Pengembangan Media Pembelajaran Matematika Berbantuan Program Flash Untuk Meningkatkan Kemampuan Matematik Siswa Smp. Jurnal Tabularasa Pps Unimed. Vol. 12 No. 2, Agustus 2015.

[9] Mulyatiningsih. E, (2013). Riset Terapan Bidang Pendidikan dan Teknik. Yogyakarta: UNY Press.

[10] Yusnawan, I.P.A. (2013). Penerapan Metode Penemuan Terbimbing Untuk Meningkatkan Pemahaman Siswa Pada Materi Gradien Di Kelas VIII SMP Negeri 9 Palu. Jurnal Elektronik Pendidikan Matematika Tadulako, 1(1): 76-86.

[11] Balım, A.G. (2009). The Effects of Discovery Learning on Students' Success and Inquiry Learnping Skills. Egitim Arastirmalari-Eurasian Journal of Educational Research, 1(35): $1-20$.

[12] Damanik. J.; Syahputra. E. (2018), Pengembangan Perangkat Pembelajaran Untuk Meningkatkan Kemampuan Berfikir Kreatif Matematis Siswa Menggunakan Model Discovery Learning. Jurnal Inspiratif, Vol. 4, No. 1 April 2018.

[13] Sugiyono, (2015), Metode Penelitian dan Pengembangan Research and Development, Alfabeta, Bandung.

[14] Borg, W., dan Gall, M. (2003). Educational Research; an Introduction $6^{\text {th }}$ edition. Boston: Pearson.

[15] Dick, W.; Carey, L. (2005). The Systematic Design of Instruction; $6^{\text {th }}$ edition. Boston: Pearson.

[16] Sinaga, B. (2008). Pengembangan Model Pembelajaran Matematika Berdasarkan Masalah Berbasis Budaya Batak (PBMB3). Medan: Universitas Negeri Medan (Laporan Hasil Penelitian Hibah Bersaing).

[17] Nieveen, N. (2007). Formative Evaluation in Educational Design Research dalam An Introduction to Educational Design Research (Ed). Disampaikan dalam seminar di East China Normal University, Shanghai, 23-26 November 2007.

(C) The Author(s) 2019. This article is an open access article distributed under the terms and conditions of the Creative Commons Attribution (CC BY) license (http://creativecommons.org/licenses/by/4.0/). 